\title{
Distribution of Placer
}

Gold in the Sixes River,

Southwestern Oregon-

A Preliminary Report

By SAM BOGGS, JR., and EWART M. BALDWIN

CONTRIBUTIONS TO ECONOMIC GEOLOGY

GE OLOGICAL SURVEY B ULLE T I N 1312-I

Prepared in cooperation with the

University of Oregon

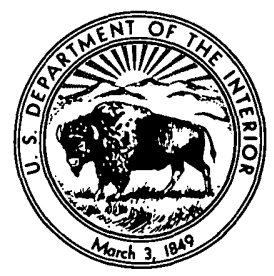




\title{
UNITED STATES DEPARTMENT OF THE INTERIOR
}

WALTER J. HICKEL, Secretary

\author{
GEOLOGICAL SURVEY
}

William T. Pecora, Director

For sale by the Superintendent of Documents, U.S. Government Printing Office Washington, D.C. 20402 - Price 25 cents (paper cover) 


\section{CONTENTS}

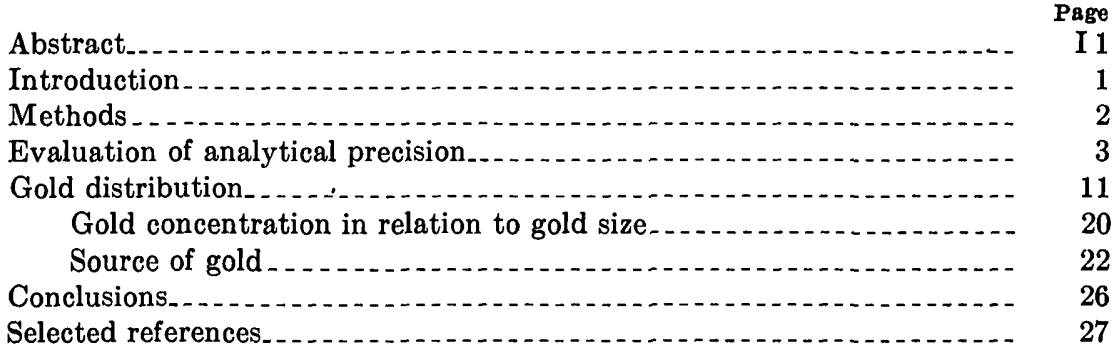

\section{L L U S TR A T I ON S}

Figure 1. Plot of $\phi$ gold size against cumulative percentage for a

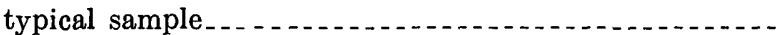

2-6. Sketch maps:

2. Average concentration of gold at each sample locality .................................... 12

3. Average size of gold at each sample locality _..... 14

4. Topographic map of pilot-study area at the mouth of the South Fork showing location of sample sites.

5. Distribution of gold at pilot-study area at the mouth of the South Fork

6. Mean size of gold at pilot-study area at the mouth of the South Fork

7. Histogram showing frequency of occurrence of the modal gold-size fraction.....................................

8. Plot of gold concentration, in parts per billion, in the total sample in relation to $\phi$ mean gold size for 126 samples.

9. Generalized rock-type map of the Sixes River drainage basin

\section{T A B L E S}

TABLE 1. Size and grade of gold in surface alluvium of the Sixes

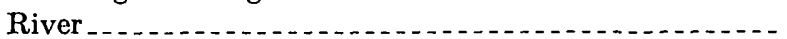

2. Frequency of occurrence of modal gold-size fraction shown as a function of total gold concentration 



\title{
CONTRIBUTIONS TO ECONOMIG GEOLOGY
}

\section{DISTRIBUTION OF PLACER GOLD IN THE SIXES RIVER, SOUTHWESTERN OREGON-A PRELIMINARY REPORT}

\author{
By Sam Boggs, JR., ${ }^{1}$ and Ewart M. Baldwin ${ }^{1}$
}

\begin{abstract}
A study of the Sixes River, a known source of placer gold, was undertaken in order to gain a better understanding of the factors controlling transportation and accumulation of gold in fluvial environments. As part of this study, 158 samples were analyzed for gold content. Data from these analyses show that gold in particles larger than about 0.15 millimeter is concentrated mainly in the South Fork of the Sixes River with lesser concentrations in the Middle Fork, Hays Creek, and the main stream between Hays Creek and the South Fork. Minor amounts of finer gold occur in all tributaries. The origin of most of the coarse gold particles appears to be related to the formation of quartz veins and the emplacement of small diorite dikes that locally intrude argillites of the Galice Formation. Some finer gold is furnished by conglomerates and sandstones of the Otter Point and Rocky Point Formations of Koch (1966) and the Umpqua Formation.

The tenor of the placer gold is highest in those samples which contain the coarsest gold, and the analyses indicate that increasing tenor generally results mainly from an increase in size of gold particles rather than an increase in number of smaller gold particles. Both the size and content of gold decrease in the lower part of the Sixes River below the junction with the South Fork. The average concentration of gold in the upper part of the alluvial fill in the lower 8-10 miles of the river is less than 1 part per billion, and the average size of the gold is less than about 0.15 millimeter. Coarser gold appears to lag behind in the upper reaches of the stream and apparently is not transported into the intertidal zone.
\end{abstract}

\section{INTRODUCTION}

A study of placer gold distribution in the Sixes River in southwestern Oregon was begun in 1967 as part of the Heavy Metals program initiated by the U.S. Geological Survey to evaluate and improve domestic sources of metals and minerals in critically short supply.

\footnotetext{
${ }^{1}$ University of Oregon, Eugene, Oreg.
} 
Placer gold has been mined from terrace gravels and recent alluvial fill in the Sixes River since the late 1800's. The present investigation was begun in a known gold province in order to develop a better understanding of the factors controlling transportation and accumulation of gold and heavy minerals and to evaluate the relative importance of the Sixes River in supplying gold to offshore areas. This report describes the distribution of gold in the upper part of the alluvial fill in the Sixes River and its major tributaries, and the probable source rocks from which the gold was derived.

Gold analyses were made by Kam W. Leong and Arthur Hubert; samples were preconcentrated under the direction of $\mathrm{H}$. E. Clifton prior to analysis (see Clifton and others, 1967). Richard Robertson, LeRoy Maynard, Saleem Farooqui, and Michael Brownfield, graduate students at the University of Oregon, assisted with field mapping and sampling. Funds for the research were provided by U.S. Geological Survey Contract 14-08-001-11058 with the University of Oregon.

\section{METHODS}

The location of sample sites on the Sixes River and its major tributaries is shown in figure 2. The number of samples collected at each sample locality, excluding locality 1 where about 40 samples were taken, ranged from one to seven depending upon local conditions. Samples, where possible, were collected at depths of 14-18 inches below the surface to insure some degree of uniformity and to facilitate comparison of results. During the summer months, at the time samples were collected, only fine silt and clay are transported by the Sixes. Water velocities become high enough to move coarser sediment and gold only during high-water conditions in winter and spring; thus the gravelly materials sampled represent flood deposits formed during the preceding season or seasons.

Clifton, Hunter, Swanson, and Phillips (1969) point out that a sample taken from a deposit' assumed to contain randomly distributed particles of gold must be of a minimum specified size for meaningful analysis; that is, the sample must be large enough to insure that the analysis will have a specified degree of precision. The degree of precision arbitrarily chosen required a 95 -percent probability that the true gold content be not much more than 50 percent larger or smaller than the gold content obtained by chemical analysis; this degree of precision is met if the sample is large enough to contain 20 particles of gold. If the approximate size and tenor of gold in a given deposit is known from reconnaissance sampling, the approximate minimum size of sample required for analysis can be estimated by reference to figure 3 of Clifton, Hunter, Swanson, and Phillips (1969). A prelim- 
inary analysis of samples from the Sixes River indicated that samples ranging in size from about 5 to 15 kilograms would be required. Because $10 \mathrm{~kg}$ is about the maximum practical size that can be transported in the field, $5-10 \mathrm{~kg}$ of material was collected from most deposits.

Prior to gold analysis, the samples (all mainly sandy gravel) were dried, weighed, and wet-sieved through a 1-millimeter sieve. Material larger than $1 \mathrm{~mm}$ was concentrated by panning and visually examined for gold. Material smaller than $1 \mathrm{~mm}$ was analyzed by wet chemical and atomic absorption spectrophotometry methods in U.S. Geological Survey laboratories in the field and in Menlo Park, Calif., by methods described by Thompson, Nakagawa, and VanSickle (1968) or by VanSickle and Lakin (1968). As part of the analytical process, 103 samples were sieved into five size fractions $(1.0-0.5 \mathrm{~mm}, 0.5-0.25$ $\mathrm{mm}, 0.25-0.125 \mathrm{~mm}, 0.125-0.0625 \mathrm{~mm},<0.0625 \mathrm{~mm}$ ) and separate analyses were made of each size fraction. The remaining samples were analyzed in three size fractions $(>0.5 \mathrm{~mm}, 0.5 \mathrm{~mm}-0.177 \mathrm{~mm}$, and $<0.177 \mathrm{~mm}$ ).

The size distribution of gold in each sample was determined from the data supplied by the gold analyses. Mean size of the particles, in $\phi$ units, was computed from cumulative curves of the gold size distribution using the following relationship (Folk, 1961):

$$
M_{z}=(\phi 16+\phi 50+\phi 84) / 3
$$

where $M_{z}$ is mean size, in $\phi$ units, and $\phi 16, \phi 50$, and $\phi 84$ are the 16 th, 50th, and 84th percentiles, respectively. Figure 1 shows a sample curve and the method of computing mean size from this curve. Size, in $\phi$ units, was converted to millimeters by use of appropriate tables. Mean gold size may also be computed from the formula:

$$
\mathrm{M}_{\phi}=\frac{\Sigma d w}{\Sigma w}
$$

where $\mathrm{M} \phi$ is mean size, in $\phi$ units, $d$ is the midpoint of each size group, and $w$ is the weight of gold, in micrograms, in each size group.

\section{EVALUATION OF ANALYTICAL PREGISION}

Table 1 shows the tenor and mean size of gold particles in surface alluvium of the Sixes River and its tributaries based on 158 samples analyzed to date. The degree to which the analyzed values represent the true gold content of the deposits sampled is a function of gold size, tenor, the degree to which the distribution of gold particles is random, the size of the samples analyzed, and the extent of analytical errors (Clifton and others, 1969). Assuming random distribution of the gold particles through the deposit and the absence of analytical errors, 


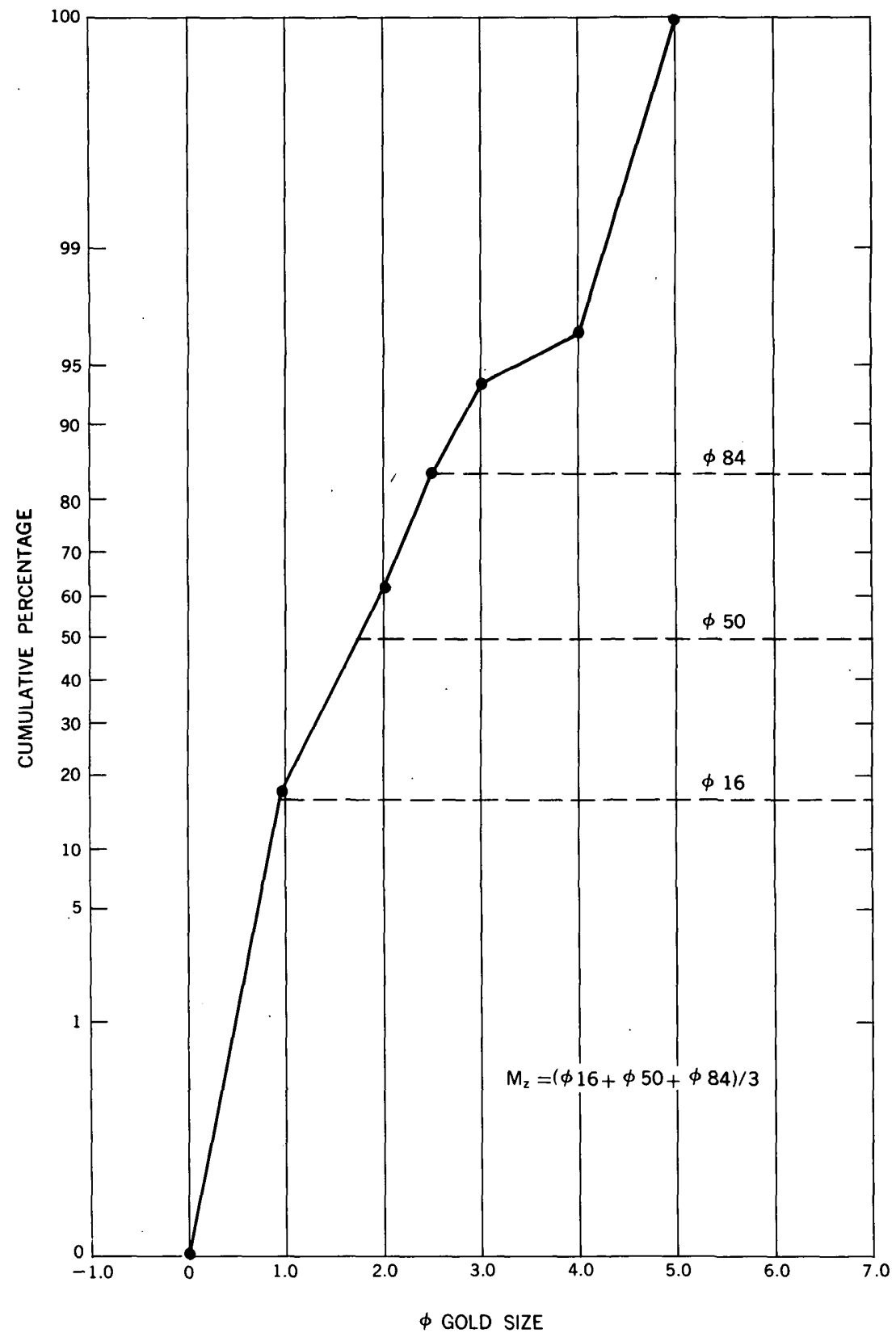

FIgURE 1.-Plot of $\phi$ gold size against cumulative percentage for a typical sample showing method of computing mean gold size from analyses of sieved samples (see text for interpretation of equation). 
the precision of the analysis is a function of the number of gold particles present in the sample. The number of gold particles can be estimated if the particle sizes and concentrations are known; from these data the approximate relative error of the analyses can be calculated. For example, a sample containing 20 particles of gold will have a relative error of about minus 35 to plus 50 percent at the 95 -percent level of confidence.

Calculation of the relative error of an analysis is based on the assumption that the gold particles are of uniform size. Variations in gold size add an additional source of error to that resulting from variations in the number of gold particles per sample. This error can be compensated for by assuming that the gold particles have some uniform size larger than the average size per gold particle in the sample. For this purpose, Clifton, Hunter, Swanson, and Phillips (1969) suggest the use of the following equation taken from the work of Pierre Gy and A. Prigogine:

$$
d_{\theta}=\left(\sum \frac{M_{j}}{M} d_{j}^{3}\right)^{1 / 3}
$$

where $d_{e}$ is the effective gold size, $M_{j}$ is the mass of gold in size grade $j, d_{j}$ is the midpoint diameter of size grade $j$, and $M$ is the total mass of gold in all size grades; the proper value for $d_{j}{ }^{3}$ is one-half the sum of the cubes of the sieve openings bounding size grade $j$. The equation places unequal weight on material in the coarser size grades, and thus effective gold size may be considerably larger than mean gold size. This provides a safety factor for determining adequate sample size when dealing with deposits containing gold of variable size.

In table 1 both the effective size and mean size of gold are given for those samples that were separated by sieving into five size fractions before analysis. The relative error and the confidence ranges of the concentrations, in parts per billion, at the 95-percent confidence level were calculated using both the effective gold size and mean gold size. The remaining samples were analyzed in only three size fractions ( $>0.5 \mathrm{~mm}, 0.5-0.177 \mathrm{~mm}$, and $<0.177 \mathrm{~mm}$ ) ; because this distribution is largely open ended, effective gold size was not calculated for these samples, and the relative error and the 95-percent confidence ranges of the concentration are shown as a function of the mean gold size only. Use of mean gold size in calculating precision of the analyses gives a relative error which, for most samples, is probably too small. These values are useful, however, for comparison with those obtained using effective gold size in the computations, and they provide an approximation of the true precision of the analyses for those samples for which effective size could not be accurately computed. 


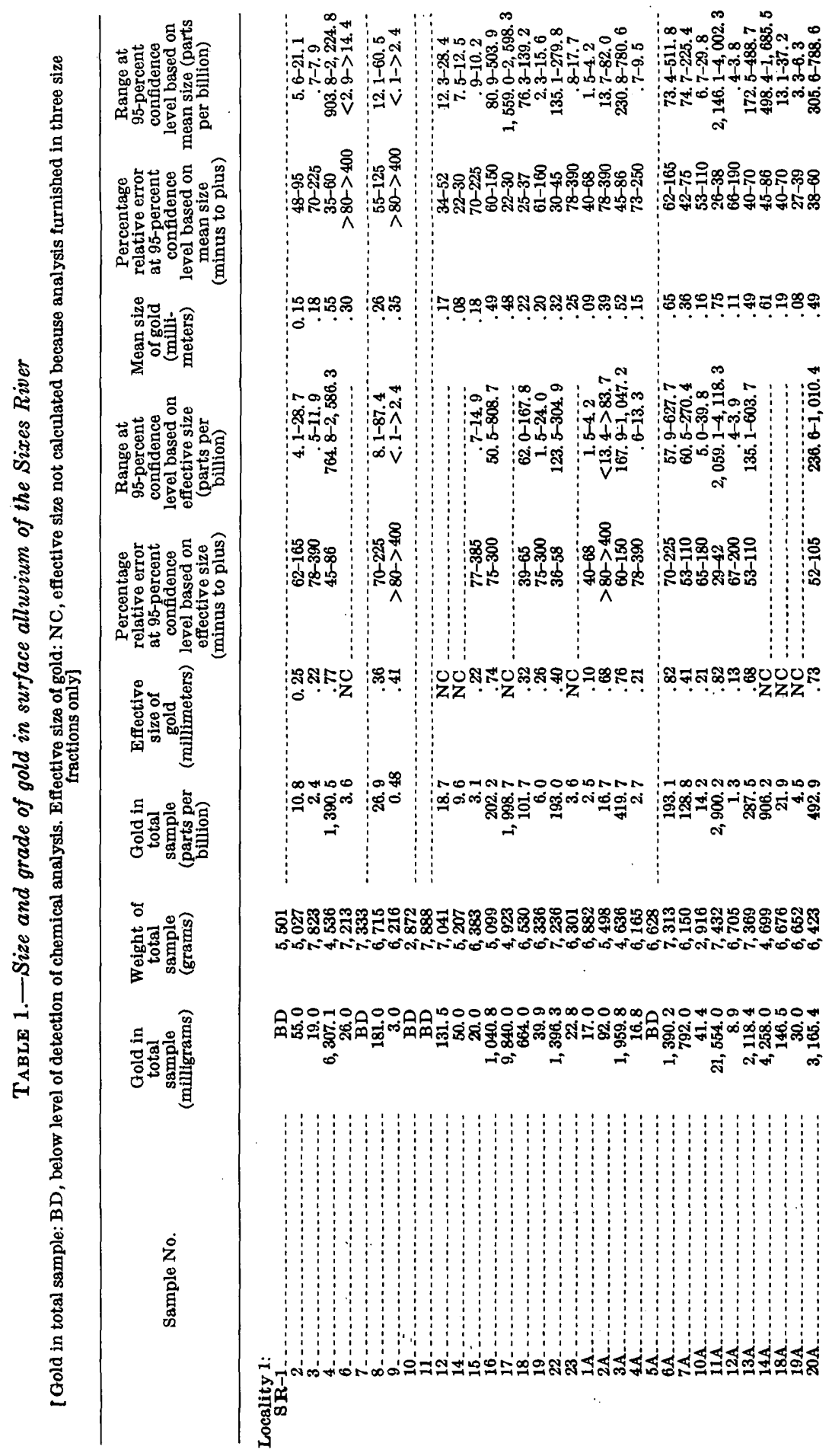




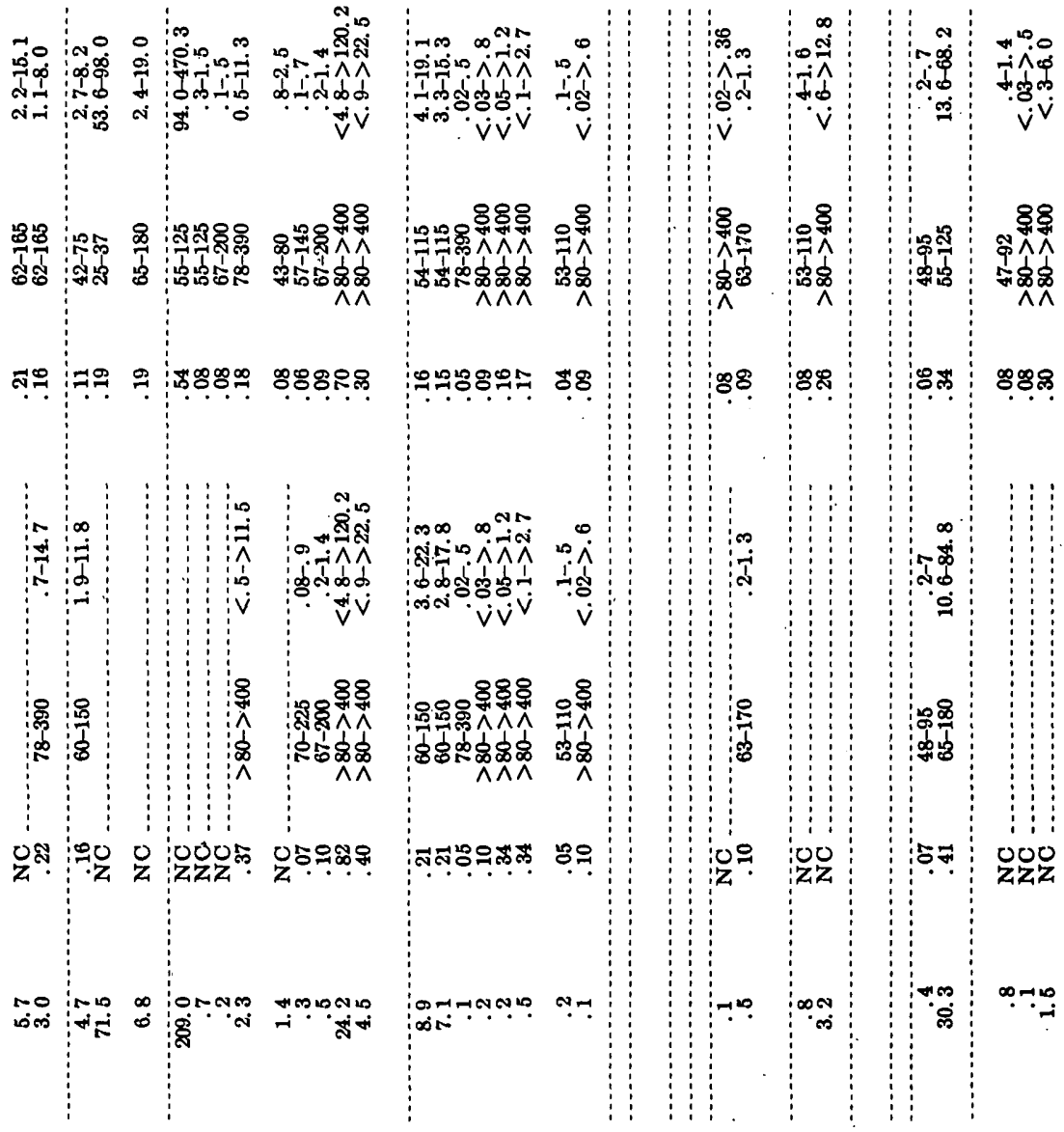

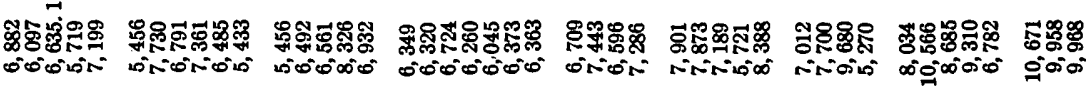

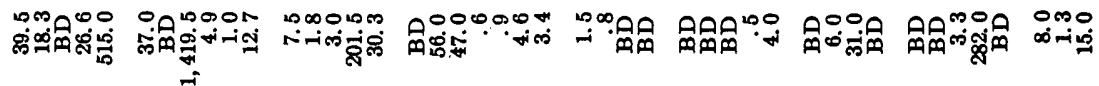

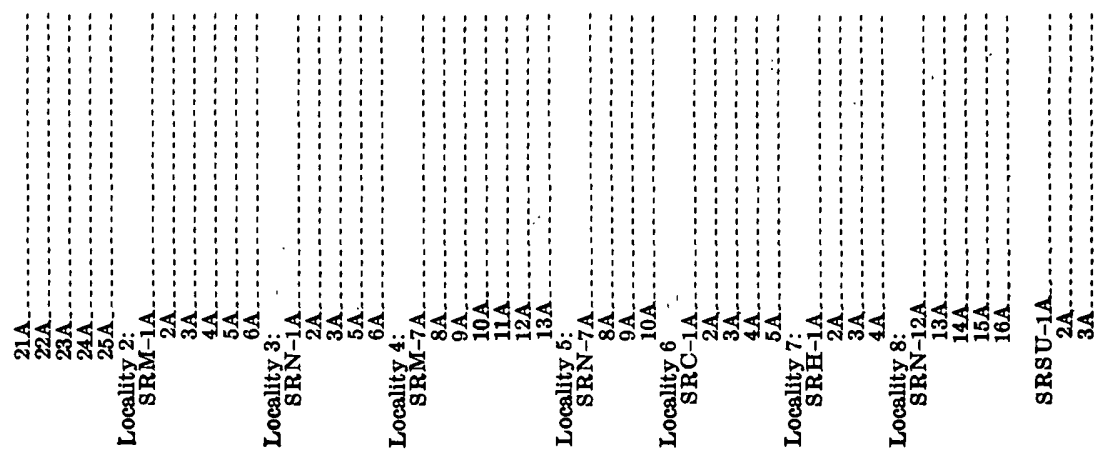




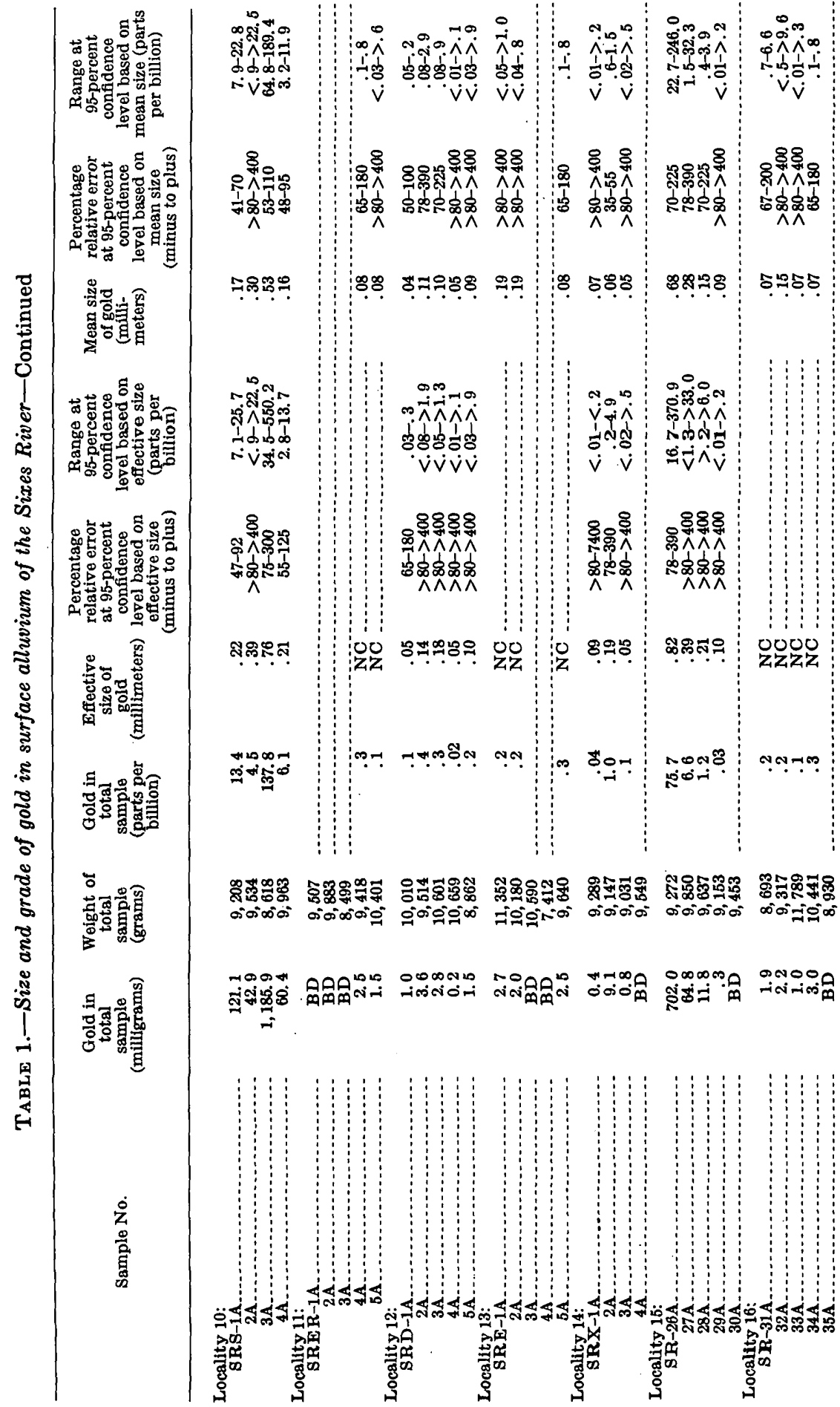




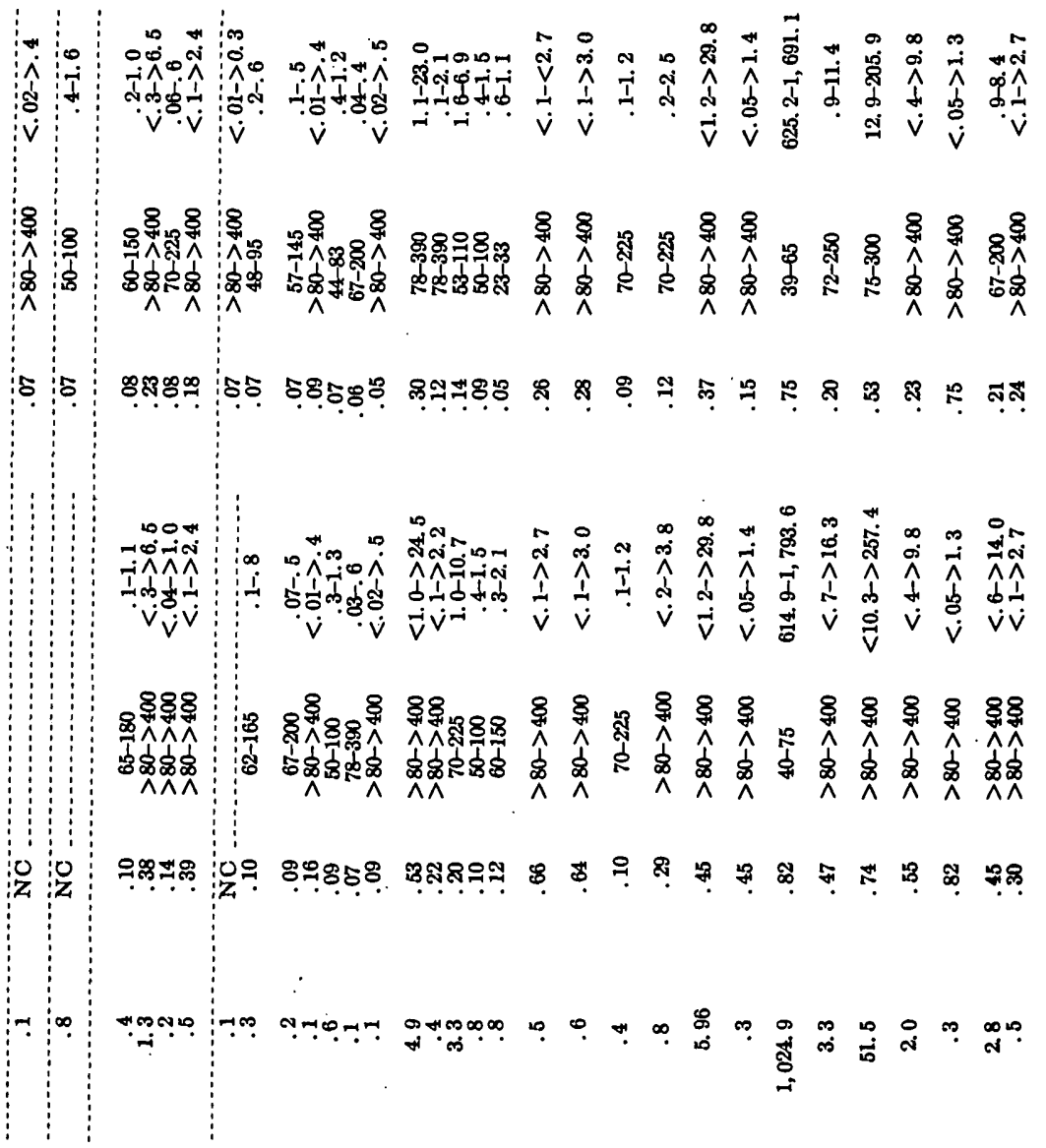

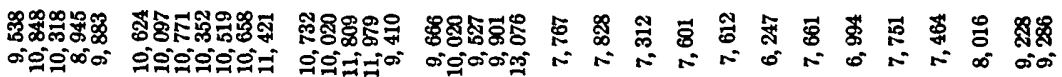
คొ

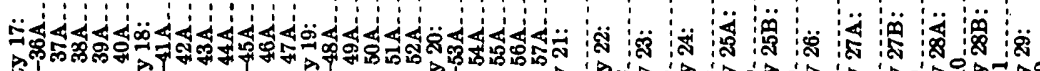

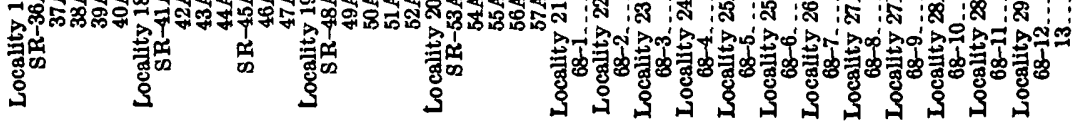




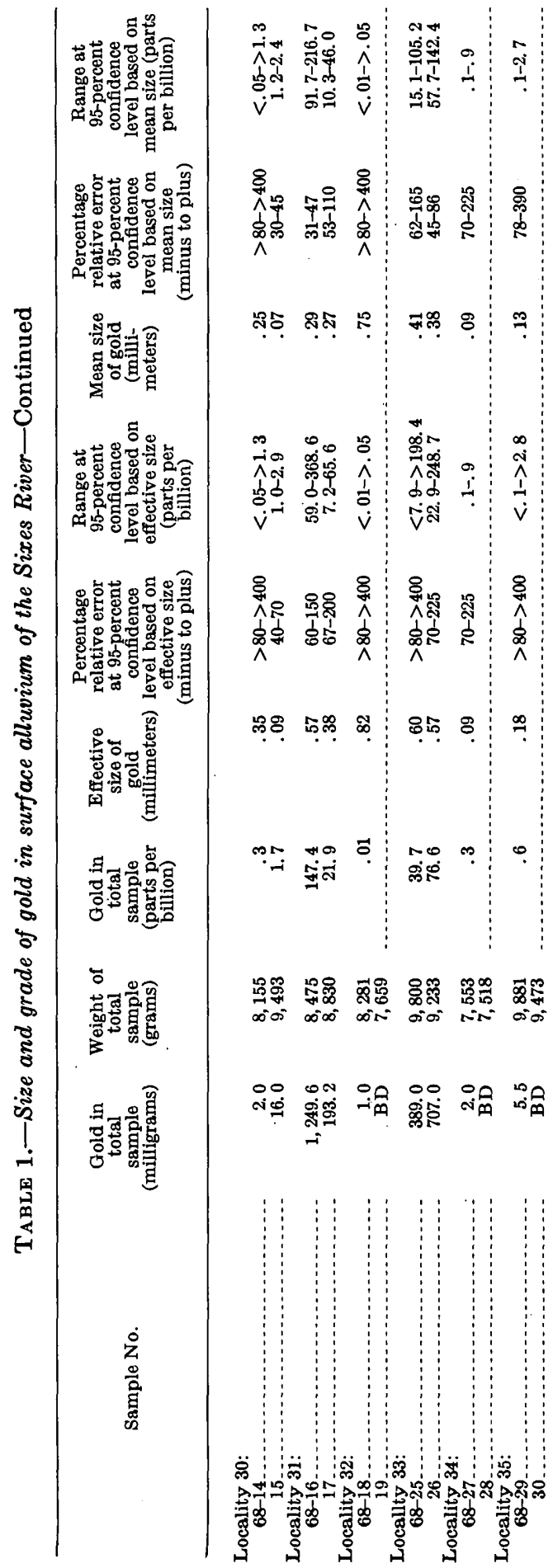


If the allowable relative error for a meaningful analysis is taken to be \pm 50 percent at the 95 -percent level of confidence-that is, the true gold content of the sample is no more than about 50 percent larger or smaller than the gold content obtained in the analysis-then table 1 indicates that analysis of many of the samples collected to date would not be meaningful. In fact, some of the deposits of very low concentrations would require sampling of more than $50 \mathrm{~kg}$ of material in order to insure the specified degree of precision. Collecting and transporting samples of this size is extremely difficult and would necessitate some type of preconcentration in the field.

The extent of analytical error is uncertain. Undoubtedly some random analytical error exists, and its effect is to decrease the precision of the analyses more than predicted from the calculated effective number of gold particles per sample. Moreover, the method of analysis used here may result in sysematic error or bias because gold included within grains not dissolved during the chemical treatment would not be revealed by the analysis. This type of systematic error, which leads to analyzed gold concentrations lower than the true gold concentration of the sample, may not be disadvantageous in an investigation such as this, in which determining the distribution of particulate gold is the objective. Other causes of systematic error are possible but cannot be evaluated at the present time.

\section{GOLD DISTRIBUTION}

Figure 2 gives the mean or average concentration of gold at each of the localities sampled. The value shown at each locality was obtained by averaging the gold concentrations of all the samples taken at that locality. Table 1 shows that the concentration of gold in individual samples varies markedly at many localities and that many of these variations are too large to be accounted for on the basis of relative error in the analyses alone. The variations indicate that gold is probably not distributed evenly or randomly within the surface alluvium at many localities, and therefore the assumption of random spacing of gold particles made in calculating relative error of the analyses can only be taken to hold true for a limited area immediately surrounding the sample site. Despite these local variations in gold content, figure 2 indicates that average gold concentration varies by several orders of magnitude between different localities in the Sixes drainage system.

The richest concentrations of gold occur in parts of the South Fork drainage, which appears to encompass a major gold source. Note the particularly high values in the area near Rusty Creek and also at the mouth of the South Fork. Other concentrations of interest occur in the Middle Fork, Hays Creek, and the main channel of the Sixes 


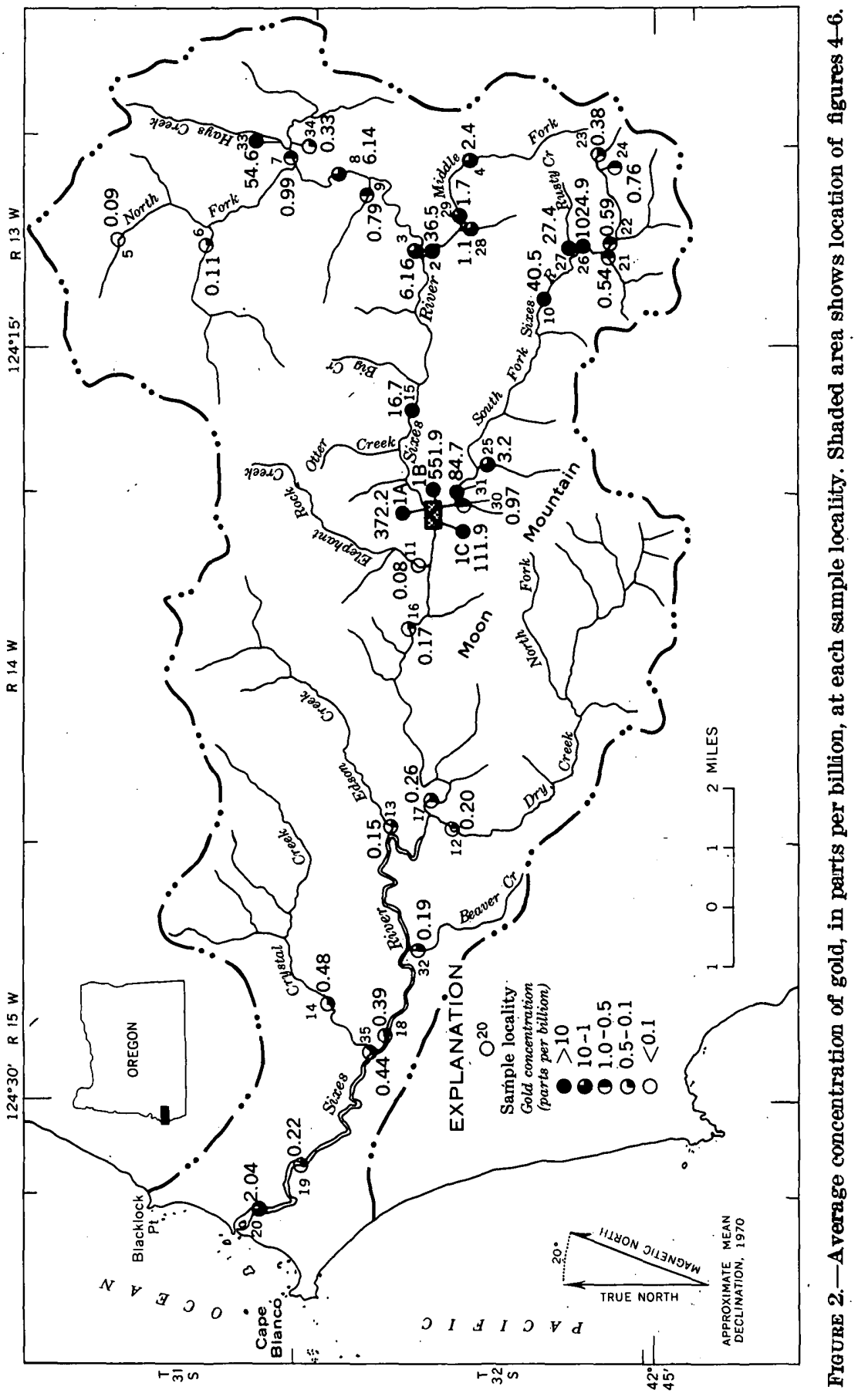


between Hays Creek and Elephant Rock Creek. All other tributaries sampled have minor amounts of gold, but most samples contain less than $1 \mathrm{ppb}$ (part per billion). The tributaries downstream from South Fork furnish little gold to the main channel, but they do contribute sizable quantities of gravel and sand. This appears to dilute the gold content of the Sixes below the South Fork, and the average gold content of samples taken from the main channel between the South Fork and the intertidal zone, extending about 3 miles upstream, is less than $1 \mathrm{ppb}$. To date, samples taken fom the intertidal zone have an average gold content of about $2 \mathrm{ppb}$.

Figure 3 shows the distribution of gold by particle size in the Sixes River drainage basin. The values given in millimeters are the averages of the mean size of gold in all samples taken from the same sample locality. Gold particles exceeding $1 \mathrm{~mm}$ were not detected in the samples analyzed; however, some gold larger than $1 \mathrm{~mm}$ was panned from localities on the South Fork by scraping material directly from the bedrock. Most gold in the samples collected is less than $0.5 \mathrm{~mm}$.

No specific pattern of size distribution is apparent in the various tributaries, but, in general, samples having the highest gold content also contain the largest gold particles. Thus the coarsest gold particles were taken from the South Fork, the Middle Fork, Hays Creek, and the main channel between Hays Creek and the South Fork. The average mean. size of gold in this part of the drainage basin ranges from 0.09 to $0.84 \mathrm{~mm}$; however, table 1 shows that many of the individual samples contain gold particles having a larger mean size than the average means given in figure 3 .

The mean size of gold particles in samples collected from the main channel of the Sixes below Elephant Rock Creek is smaller than that from the upper Sixes region, and mean gold size diminishes rather abruptly below the junction with the South Fork. This may be due mainly to the decreased gradient of the Sixes below this point and to the fact that very little coarse gold is supplied to the downstream part of the main channel by tributaries. Because of the dilution effect mentioned above, there is also less likelihood of finding coarse gold particles in a particular sample at a given locality in the lower part of the stream should such coarse gold be present. Therefore, gold coarser than these data indicate may be present in the surface alluvium of the downstream part of the main channel. However, in 27 samples taken from the lower part of the channel, only four samples contained gold particles having a mean size in excess of $0.15 \mathrm{~mm}$. Although further data are needed for confirmation, these data suggest that most gold particles in the upper few feet of surface alluvium in the intertidal zone, and thus the particles most likely to be transported ultimately 


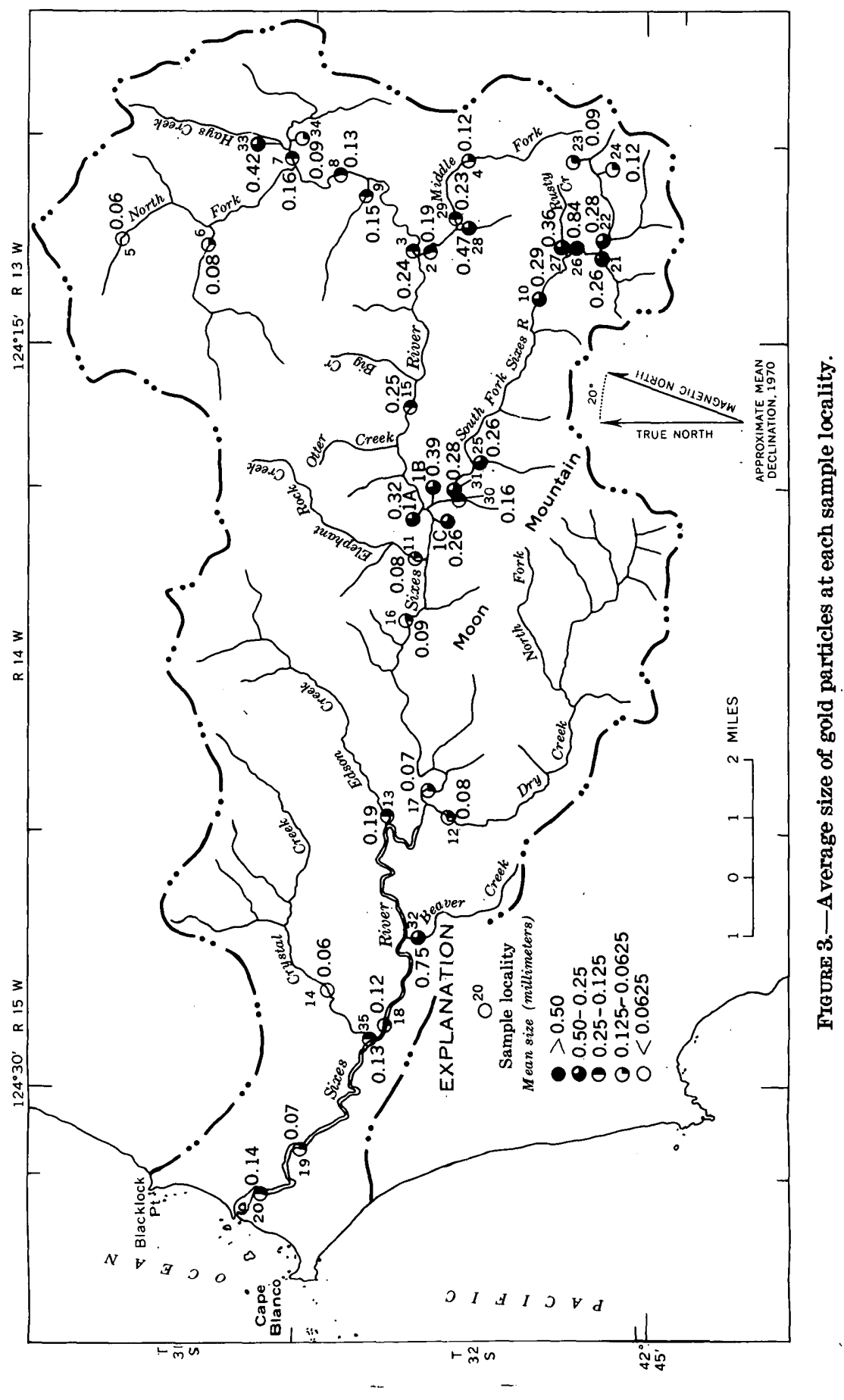


into the ocean, are probably less than about $0.15 \mathrm{~mm}$ in size. However, gold coarser than this may be present in the deeper channel fill.

The surface detritus on the bars and in the stream in the Sixes River is mainly granule and gravel size $(2 \mathrm{~mm}$ and larger). This material does not move during the extremely low water conditions existing during the summer months, when collections were made, but is transported only during flood stage of the river in winter and spring. In order to learn more about the factors favoring concentration of gold in such gravelly "flood" deposits, a detailed study was made of a small area at the mouth of the South Fork of the Sixes. This area was selected for study because preliminary panning indicated that both the streambed and the gravel bars contained gold. The area was mapped by plane-table methods (fig. 4) and a grid sampling pattern laid out to facilitate collection of random samples. Additional samples were taken between grid points where additional control appeared to be necessary. The size distribution of the surface detritus was mapped onto this base (fig. 5) to aid in determining whether a relationship exists between gold size, tenor, and the size of the detritus with which gold occurs.

Figure 5 shows the distribution of gold in the pilot-study area based on 39 samples. The greatest concentrations of gold occur in three places: (1) in the exposed bar adjacent to bedrock along the east side of the Sixes above the junction with the South Fork, (2) in the middle and upper parts of the large bar south of the junction at the forward (stream) edge of the bar and in the stream channel at the upstream end of this bar in the South Fork, and (3) near the back of the upstream part of the bar on the north side of the Sixes below the junction with the South Fork. The highest gold concentrations occur with surface materials that are either mainly cobbles and boulders or mixed pebbles, cobbles, and boulders. Below the immediate surface layer of pebbles, these deposits also contain considerable interstitial sand ( $15-45$ percent).

The greatest concentration of gold in the large bar south of the junction is in the upstream portion of the bar. Where the bar broadens out below the junction, gold is concentrated near the stream edge of the bar rather than at the back edge. This bar has a relief of about 6-7 feet above stream level at this point, and the gold apparently concentrates near the stream level rather than in the higher part of the bar: In the Sixes River above the junction, gold is also concentrated in the coarser material. The exposed bar is $2-3$ feet above stream level, and richest concentrations of gold are toward the back side of the bar. only a few feet of detritus is present here above bedrock, and irregularities in the underlying bedrock probably have helped concentrate 


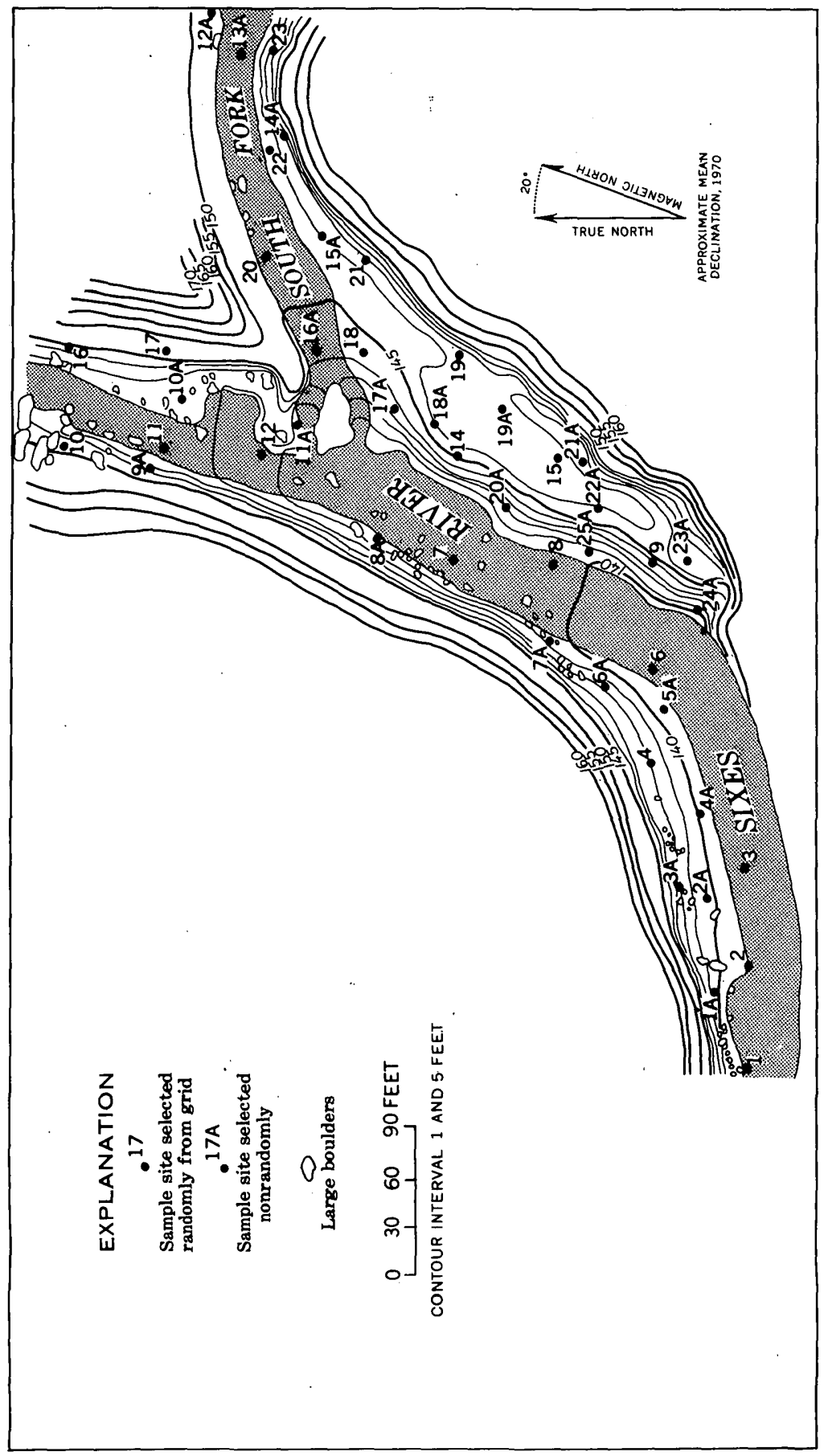

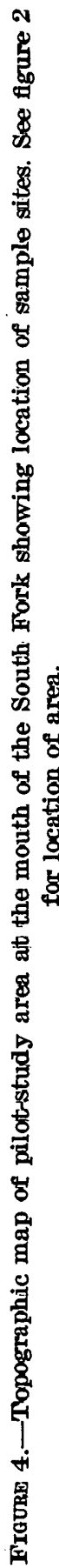




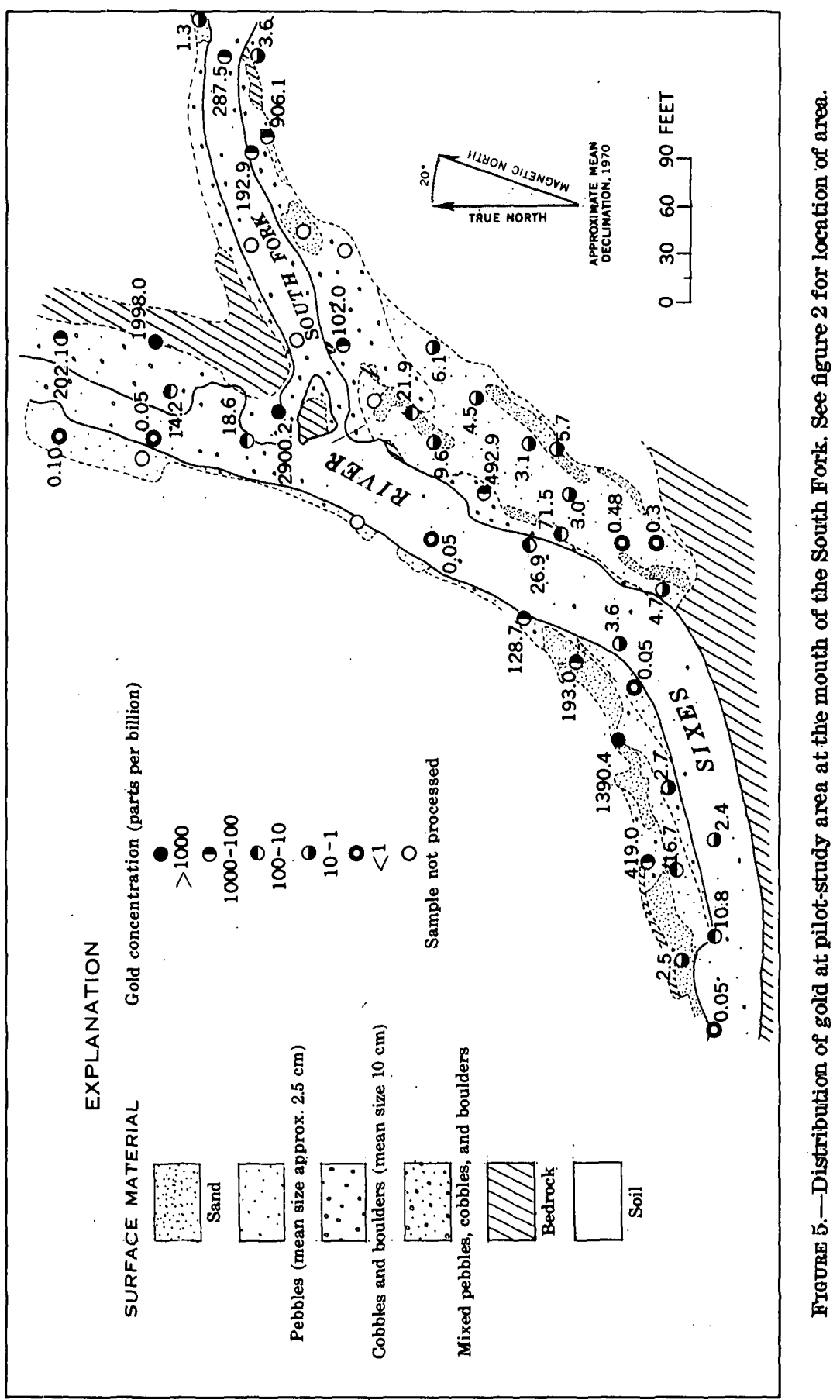


the gold. In the bar downstream from the junction on the north side of the stream, best concentrations were found in samples collected from sites at which the surface material was either sand or mixed pebbles, cobbles, and boulders. The sand at these sites is only a thin veneer, 2-4 inches thick, and below this the deposits become quite gravelly. Relief on this bar is about 3 feet above stream level, and gold is concentrated in the upstream part of the bar toward the back side. Bedrock here also is only a few feet below the surface.

Figure 6, which is plotted on the same base as figure 5, shows the distribution of gold by size in the pilot-study area. A comparison of figure 5 and figure 6 indicates a correlation between the tenor of gold in the samples and the mean size of the gold; samples having the highest concentrations of gold also contain the coarsest gold particles. Thus the coarsest gold tends to occur with the coarsest detritus, in the upstream parts of bars, toward the back side of the low-relief bars and the front (stream) edge of the high-relief bars, and in areas where bedrock is fairly close to the surface. The concentration and size of gold in the active stream bed (now covered with water) is generally similar to that in the near-stream part of the adjacent bars.

Except for the pilot-study area, one to seven samples were collected from all sample localities. Sample sites were chosen from different parts of the stream and bars in order to provide additional information regarding the local distribution of gold in stream channels and bars. At most sample localities the highest concentrations of gold occur in the coarsest material available at the sample site; however, a few exceptions were found. Also higher concentrations generally came from the upstream parts of the bars rather than the downstream parts, although again some execptions were found. Many of the samples collected from the coarse detritus in the active stream channel also had relatively high concentrations. In addition the position above bedrock at which samples were collected is important. Samples collected from immediately above bedrock are almost always richer in gold than other samples collected in the same area but at a greater height above bedrock; thus the back sides of bars, where bedrock is generally closest to the surface, generally show relatively higher concentrations than other parts of the bar or stream.

Although some deposits consisting mainly of sand occur in the Sixes, most of the sand is deposited in the interstitial spaces in the gravel deposits. The amount of sand in such deposits ranges from 15 to 45 percent in most samples; in a few samples, it makes up more than 50 percent. Highest gold concentrations are generally in samples that have relatively low sand content, and the concentrations of gold in the few samples that contain more than 50 percent sand is rather low. 


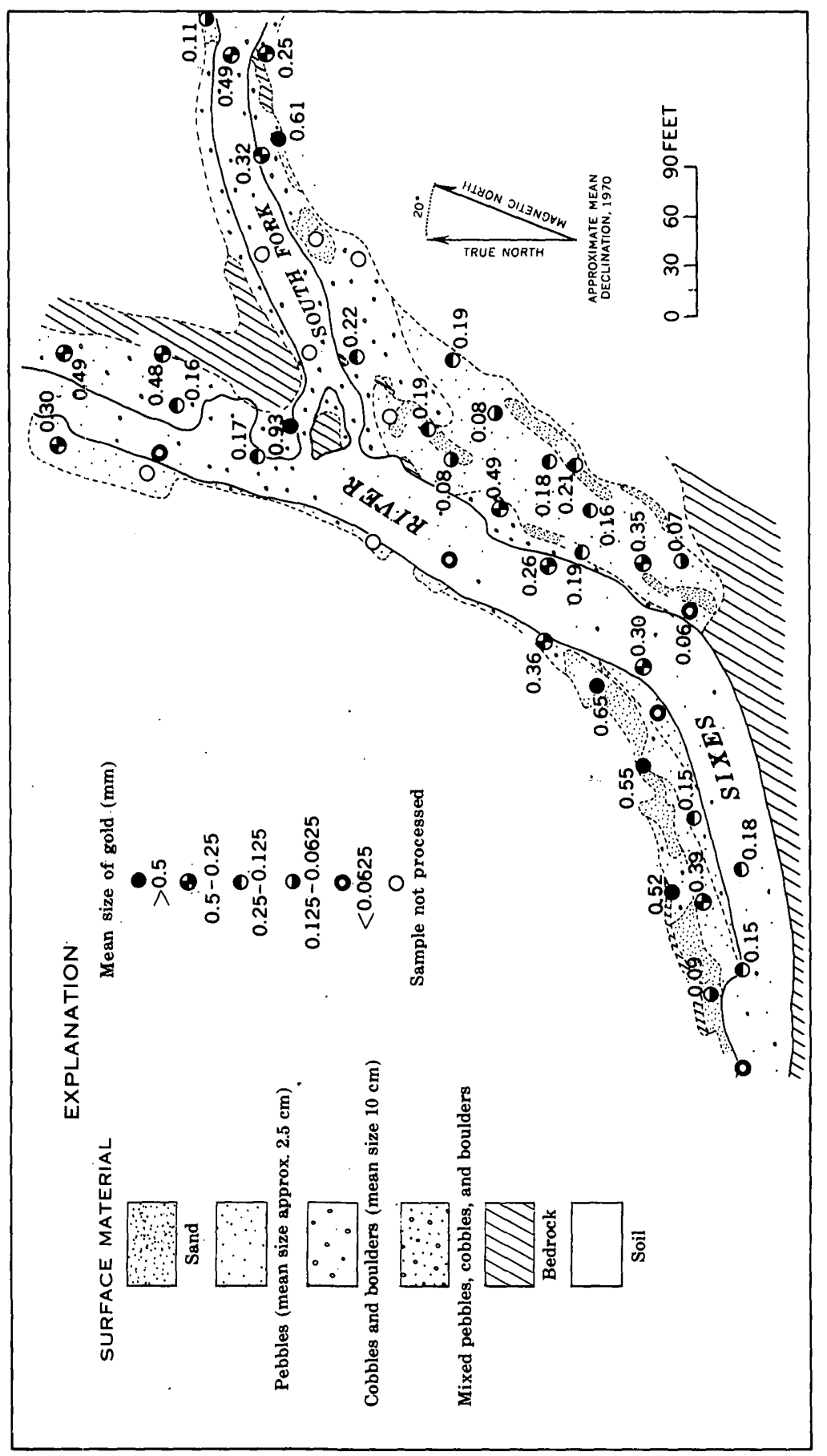




\section{GOLD CONCENTRATION IN RELATION TO GOLD SIZE}

The tenor of a gold deposit may increase as a result of increasing numbers of fine gold particles of a given size or sizes, increasing size of gold particles without significant increase in numbers of particles, or any combination of these. Comparison of figures 2 and 3 and of figures 5 and 6 seems to show that the increased tenor of most of the deposits of high concentration in the Sixes River is associated with increased grain size. In order to determine whether this may be purely fortuitous, the data from 93 samples, each of which was sieved into five size fractions before analysis, were examined to determine whether gold tends to occur preferentially in any particular size range. The data indicate that 76 percent of the samples contains gold in two or more size fractions, and 11 percent of the samples contains gold in all five size fractions. The data show further that the size fraction in each sample in which the amount of gold is greatest (modal size fraction) varies from sample to sample. Figure 7, in which the frequency of occurrence is plotted as a function of the modal gold-size fractions, shows that highest amounts of gold occur in size fractions ranging from the $<0.0625-\mathrm{mm}$ fraction to the $1.0-0.5 \mathrm{~mm}$ fraction; however, the "modal" size of the gold in two-thirds of the samples does lie between 0.0625 and $0.5 \mathrm{~mm}$.

Because these data show that gold in the Sixes River occurs in a range of sizes, a further check was made to see if a relationship exists between the modal gold-size fraction and the total concentration of gold in the sample. For 89 of the 93 samples used (four samples do not have a single modal size fraction), table 2 shows the frequency of occurrence of the modal gold-size fraction in relation to the concentration of gold, in parts per billion, in the total sample. Italic figures represent the maximum number of samples in which a particular modal size fraction occurs in each concentration group. For example, in 21 samples with total concentrations of gold ranging from 1 to 10 $\mathrm{ppb}$, the modal gold-size fraction of 11 of the samples is the 0.25 $0.125 \mathrm{~mm}$ size fraction. Note that the italic values form a distinct linear progression from lowest to highest concentrations; that is, in deposits of low gold concentration the "modal" size occurs preferentially in the fine-size fractions, and in deposits of higher concentrations it occurs preferentially in the coarse-size fractions.

It is expected on the basis of the relationship of particle mass and size (see fig. 3 of Clifton and others, 1969) that most of the gold in samples of very low tenor would be of very fine size. The few seeming exceptions to this shown in table 2 are probably the result of fine grains of gold included on the surface of larger silioate grains. In samples of higher concentrations, the gold might be either coarse 


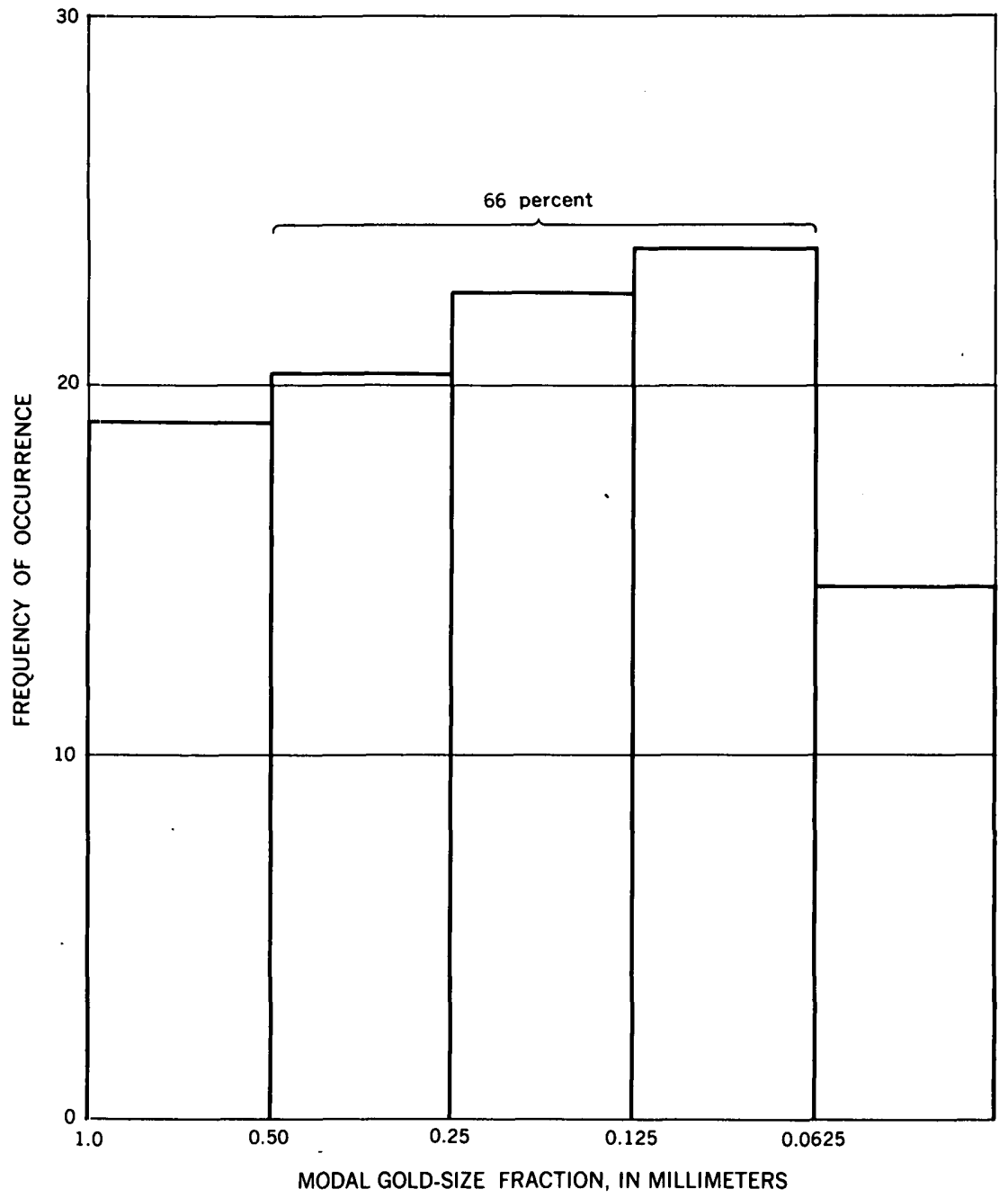

Frgure 7.-Histogram showing frequency of occurrence of the modal gold-size fraction. (Four of the 93 samples do not have a single modal size fraction and therefore are not included.)

or fine. The relationship shown in table 2, however, seems to indicate that the increase in tenor of the samples studied is due mainly to increasing gold-particle size rather than increasing numbers of fine gold particles.

As a last check on the relationship of gold size in relation to gold concentration, mean gold size was plotted against total gold concentration, in parts per billion, as shown in figure 8. In order to give some 
TABLE 2.-Frequency of occurrence of modal gold-size fraction shown as a function of total gold concentration

[Italic figures are maximum values]

\begin{tabular}{|c|c|c|c|c|c|c|c|c|}
\hline \multirow[t]{2}{*}{ Size fraction (millimeters) } & \multicolumn{6}{|c|}{$\begin{array}{l}\text { Number of samples having indicated gold con- } \\
\text { centration, in parts per billion, and having } \\
\text { modal gold size in given fraction }\end{array}$} & \multirow[t]{2}{*}{$\begin{array}{l}\text { Number } \\
\text { of samples }\end{array}$} & \multirow[t]{2}{*}{$\begin{array}{l}\text { Percent- } \\
\text { age of } \\
\text { total }\end{array}$} \\
\hline & $<0.1$ & $0.1-1$ & $1-10$ & $10-100$ & $100-1000$ & $>1000$ & & \\
\hline $\begin{array}{r}1.0-0.5 \\
0.5-25 \\
0.25-125 \\
0.125-0625 \\
<.0625 \\
\quad \text { Total }\end{array}$ & $\begin{array}{l}1 \\
0 \\
0 \\
3 \\
4 \\
8\end{array}$ & $\begin{array}{r}3 \\
4 \\
4 \\
15 \\
9 \\
35\end{array}$ & $\begin{array}{r}0 \\
7 \\
11 \\
3 \\
0 \\
01\end{array}$ & $\begin{array}{r}4 \\
5 \\
3 \\
0 \\
0 \\
12\end{array}$ & $\begin{array}{r}6 \\
2 \\
2 \\
0 \\
0 \\
10\end{array}$ & $\begin{array}{l}3 \\
0 \\
0 \\
0 \\
0 \\
3\end{array}$ & $\begin{array}{l}17 \\
18 \\
20 \\
21 \\
13 \\
89\end{array}$ & $\begin{array}{r}19.0 \\
20.3 \\
22.5 \\
23.6 \\
14.6 \\
100.0\end{array}$ \\
\hline
\end{tabular}

idea of the relative precision of the analyses, the data points are identified by symbols that indicate the range in relative error of the analyses. In this plot all samples that contained gold were used. The values show an appreciable amount of scatter, and the precision of some of the analyses is low ; nevertheless, a clear trend is evident, and an approximate best-fit line has been visually adjusted to the data. The slope of this line indicates a general increase in mean gold size with increasing total gold concentration in the samples. Increasing $\phi$ values indicate decreasing grain size: $\phi=-\log _{2}$ grain size, in millimeters.

\section{SOURCE OF GOLD}

Although parts of the South Fork and the lower Sixes have been worked extensively for placer gold, efforts to locate the lode source of the gold have been largely unsuccessful. Diller (1903) reports some lode mining on Rusty Butte (Harrison Property) both in igneous rock and in quartz veins intruded into "slate." Most of the gold was found in small pockets and veins, and Diller concludes, "It is pockets and seams of this character chiefly that have supplied the placer gold of the streams and beach gravels. Their small size, irregularity, and lack of persistence are not encouraging features." Butler and Mitchell (1916) report a claim (P. L. Wallis Quartz Claim) somewhere between the mouth of the South Fork and Rusty Creek but state, "the prospect was not sampled, and no information concerning the grade of the vein matter was procurable." Brooks and Ramp (1968) report two other lodes in the Rusty Butte area of the South Fork that are listed in Oregon State Mine File Reports, published in 1938 and 1950. However, they state that production from lode mines in this area has been negligible. A map included with the Brooks and Ramp report shows the location of some of the placers worked on the Sixth River. Almost all the placer workings are either on the South Fork or on the main stream below the junction with the South Fork, and according to 
Brooks and Ramp, many of the placers were in terrace gravels from 50 to 130 feet above the present stream level.

Four types of potential source rocks for placer gold crop out within the Sixes River drainage basin (see fig. 9).

1. Intrusive igneous rocks, mainly diorite.

2. Sandstones, argillites, and greenstone of the Galice Formation, Jurassic, locally intruded by diorite dikes.

3. The Humbug Mountain Conglomerate of Koch (1966), Cretaceous.

4. Sandstones and conglomerates of the Otter Point Formation of Koch (1966), Jurassic; Rocky Point Formation of Koch (1966), Cretaceous; and Umpqua Formation, Tertiary.

In order to determine the relative importance of each of these potential source rocks, samples were collected from various tributaries which drain exclusively or almost exclusively each of these rock types. Analyses of these samples show that tributaries whose sources are in sandstone units have very low concentrations of fine gold ranging from values below the level of detection of chemical analysis up to a maximum of about $1 \mathrm{ppb}$. Tributaries that drain conglomeratic units exclusively, or in which extensive conglomeratic deposits crop out, have somewhat higher concentrations ranging from about 1 to $3 \mathrm{ppb}$. The major intrusive body in the Sixes River drainage basin is a small diorite stock which intrudes the Galice Formation and crops out in Josh Creek and Benson Creek in the headwaters of the South Fork. Samples collected from Josh Creek and Benson Creek contain very low

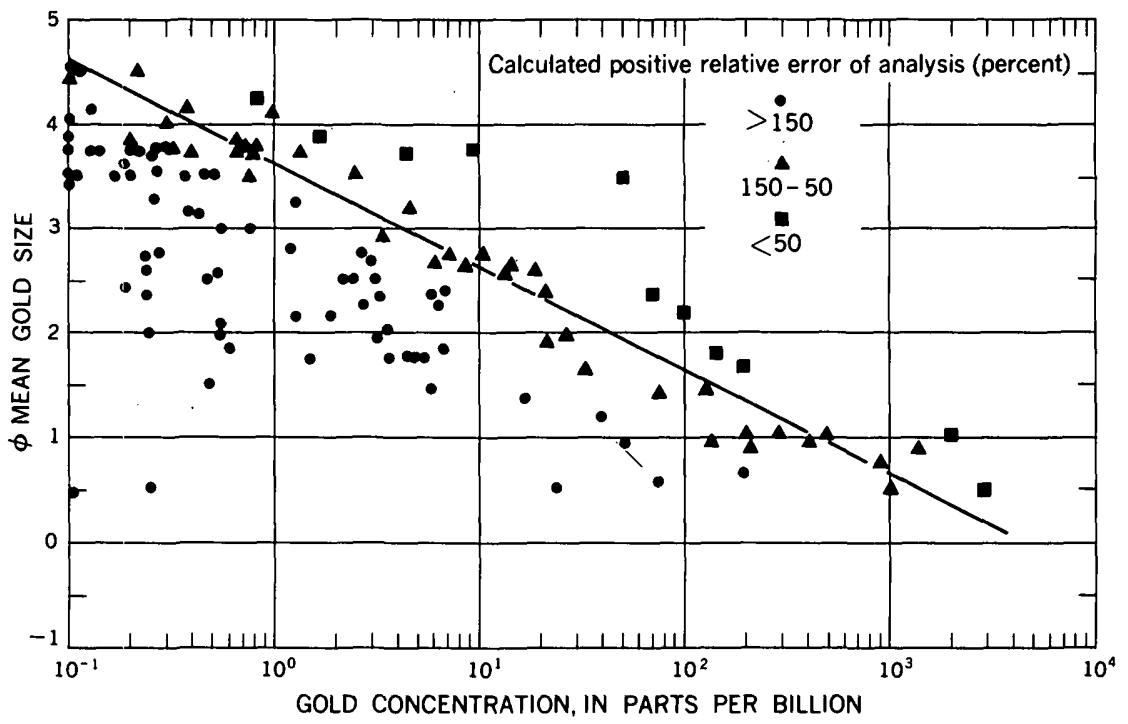

Frgure 8.-Plot of gold concentration, in parts per billion, in the total sample in relation to $\phi$ mean gold size for 126 samples. 


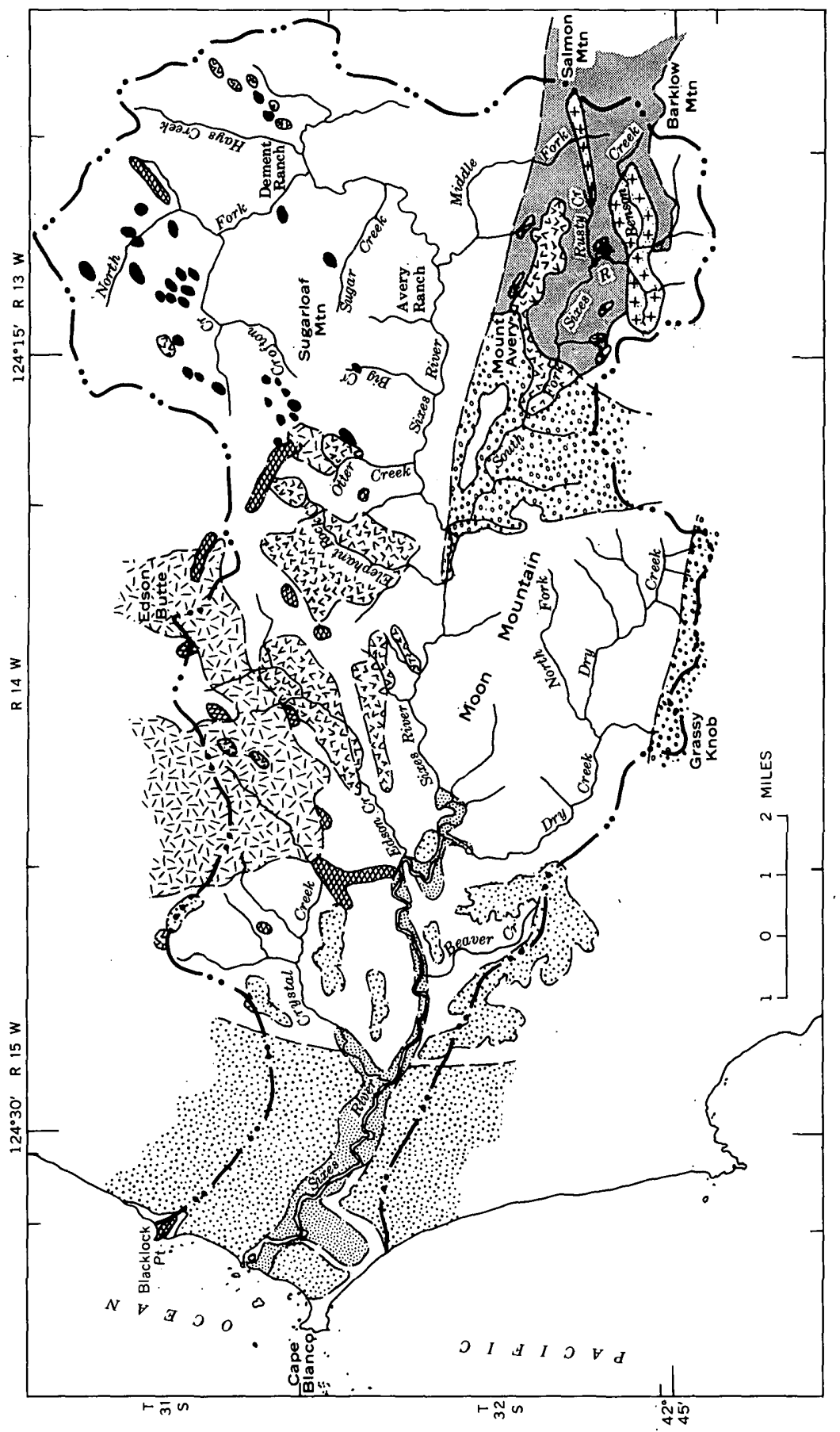




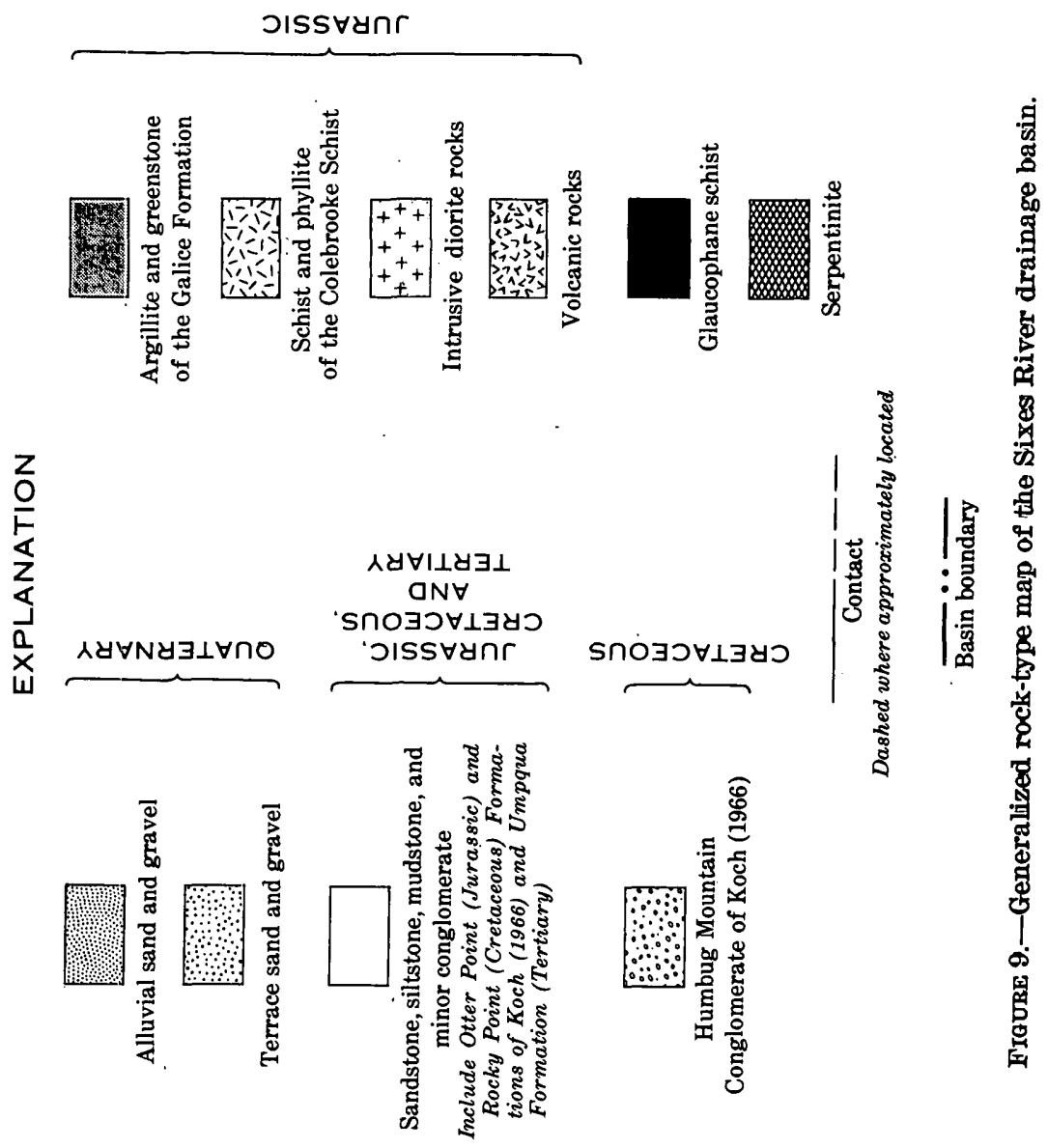


gold concentrations (less than $1 \mathrm{ppb}$ ), however, as do samples from the upper part of Benson Creek, which drains mostly nonintruded Galice argillite. Samples taken from the lower part of the South Fork, particularly from around Rusty Creek and below, contain the richest concentrations and the coarsest gold found within the Sixes drainage basin. In the area around Rusty Creek, Galice argillite is locally intruded by numerous small dikes, probably emplaced at about the same time as the Benson Creek stock. The origin of most of the placer gold in the South Fork thus appears to be related to these small intrusive bodies rather than to any large lode source.

\section{CONCLUSIONS}

The richest concentrations of placer gold in surface alluvial fill in the drainage basin of the Sixes River are in the South Fork, the Middle Fork, Hays Creek, and the main stream between Hays Creek and the South Fork. Bedrock in the drainage basin includes intrusive igneous (diorite) bodies, argillite and sandstone of the Galice Formation, and conglomerate and sandstone of the Otter Point and Rocky Point Formations of Koch (1966) and the Umpqua Formation. In order of decreasing relative importance, source rocks for the placer gold are (1) fractured and intruded Galice argillite, (2) conglomerates, and (3) sandstones. Although no lodes of importance have been discovered, the principal source of primary coarse gold in the drainage basin of the Sixes River appears to be the Galice Formation in the headwaters of the South Fork, where this formation is locally fractured and permeated with small diorite dikes and associated intrusives. Conglomerates and sandstones are a much less important source of fine second-cycle gold.

Tenor of surface alluvium in the Sixes River varies markedly from locality to locality. It is expected on the basis of the relationship of particle mass to particle size (Clifton and others, 1969) that deposits of very low tenor will contain only very fine gold, whereas deposits of higher tenor may contain either large numbers of very fine gold particles or a few much larger gold particles. Data from the analysis of 158 samples indicate that increase in tenor of deposits in the Sixes River is related more closely to increase in size of gold particles than to increase in number of small gold particles.

Highest concentrations of gold and the coarsest gold in the upper part of the alluvial fill are generally associated with the coarsest detritus at a given locality and occur preferentially in the upstream parts of the gravel bars toward the back side of low-relief bars, where alluvial fill above bedrock is shallowist, and toward the front (stream) edge of high-relief bars. Both size and tenor of gold in the Sixes 
River decrease in the lower parts of the stream below the junction with the South Fork. The average concentration of gold in the surface alluvium of the lower 8 to 10 miles of the Sixes River is less than 1 $\mathrm{ppb}$, and the mean size of most gold particles is less than $0.15 \mathrm{~mm}$.

Thus the mean size of most gold particles furnished to the intertidal zone, and eventually to the ocean, is probably less than about $0.15 \mathrm{~mm}$.

\section{SELECTED REFERENCES}

Baldwin, E. M., 1965, Geology of the south end of the Oregon Coast Range Tertiary basin : Northwest Sci., v. 39, no. 3, p. 93-103.

Brooks, H. C., and Ramp, L., 1968, Gold and silver in Oregon : Oregon Dept. Geology and Mineral Industries Bull. 61, $337 \mathrm{p}$.

Butler, G. M., and Mitchell, G. J., 1916, Preliminary survey of the geology and mineral resources of Curry County, Oregon: Oregon Bur. Mines and Geology, Mineral Resources Oregon, v. 2, no. 2,134 p.

Clifton, H. E., Hubert, Arthur, and Phillips, R. L., 1967, Marine sediment sample preparation for analysis for low concentrations of fine detrital gold: U.S. Geol. Survey Cir. 545, 11 p.

Clifton, H. E., 1968, Gold distribution in surface sediments on the continental shelf of southern Oregon, a preliminary report: U.S. Geol. Survey Cir. $587,6 \mathrm{p}$.

Clifton, H. E., Hunter, R. E., Swanson, F. J., and Phillips, R. L., 1969, Sample size and meaningful gold analysis: U.S. Geol. Survey Professional Paper 625-C, $17 \mathrm{p}$.

Diller, J. S., 1903, Description of the Port Orford quadrangle, Oregon: U.S. Geol. Survey Atlas, folio 89.

Folk, R. L., 1961, Petrology of sedimentary rocks : Austin, Tex., Hemphill's, 170 p.

Griggs, A. B., 1945, Chromite-bearing sands of the southern part of the coast of Oregon : U.S. Geol. Survey Bull. 945-E, p. 113-150.

Koch, J. C., 1966, Late Mesozoic stratigraphy and tectonic history, Port OrfordGold Beach area, southwestern Oregon coast: Am. Assoc. Petroleum Geologists Bull., v. 50, no. 1, p. 25-71.

Thompson, C. E., Nakagawa, H. H., and VanSickle, G. H., 1968, Rapid analysis for gold in geologic materials, in Geological Survey research 1968: U.S. Geol. Survey Prof. Paper 600-B, B130-B132.

VanSickle, G. H., and Lakin, H. W., 1968, An atomic-absorption method for determination of gold in large samples of geologic materials: U.S. Geol. Survey Circ. 561, 4 p.

Wells, F. G., 1955, Preliminary geologic map of southwestern Oregon west of meridian $122^{\circ}$ West and south of parallel $43^{\circ}$ North: U.S. Geol. Survey Mineral Inv. Field Studies MF-38, scale $1: 250,000$. 